\title{
Reducing runoff and soil loss using corn stalk juice at plot scale
}

\author{
Xia Wei ${ }^{1,2^{*}}$, Xungui $\mathrm{Li}^{1}$, Ning Wei ${ }^{3,4}$ \\ ${ }^{1}$ Key Laboratory of Western China's Environmental Systems (Ministry of Education), Colleg \\ e of Earth and Environmental Sciences, Lanzhou University, 222 South Tianshui Road, Lanzh \\ ou, Gansu Province 730000, China \\ ${ }^{2}$ Agronomy Department, Purdue University, and USDA-ARS National Soil Erosion Research \\ Lab., 275 South Russell Street, West Lafayette, Indiana, 47907-2077, USA
}

${ }^{3}$ College of Science, Northwest Agriculture \& Forester University, Yangling 712100, China

${ }^{4}$ Economics and Business Adiministration, Chongqing Univerity, Chongqing 400030, China

*Corresponding author:

Xia Wei, College of Earth and Environmental Sciences, Lanzhou University, 222 South

Tianshui Road, Lanzhou, Gansu Province 730000,China. E-mail: weix@lzu.edu.cn, Tel:

$+86-13893459360$.

\begin{abstract}
Soil erosion control is the most essential principle for the sound utilization of soil and water. Application of soil amendments is considered as an appropriate and new strategy for soil erosion control. Despite the application of different amendments used for soil and water conservation, effects of corn stalk juice to control erosion and reduce runoff have not been considered yet. Corn stalk juice is a byproduct differentially utilized for green biomass,
\end{abstract}


for example, as an energy source or a natural fiber material. The present study was conducted to evaluate the performance of the application of corn stalk juice on the runoff and erosion control of Crosby-Miami complex Alfisol packed in small-sized plots with three replicates. The study was performed under laboratory conditions using rainfall simulation and four small plots with 5\% slope. Experiments were then set up as one control and six different treated plots (named as T1, T2, T3, T4, T5 and T6) with two volumes of $0.4,0.8 \mathrm{~L}$ and three concentrations of $25 \%, 50 \%, 75 \%$ and subjected to simulated rainfall, respectively. The results showed that the corn stalk juice had positive effects on runoff and erosion control. The effects of the high volume and concentration of corn stalk juice on runoff and erosion were both better than those of the low ones. The high corn stalk juice concentration was more effective on runoff and erosion reduction compared with the low corn stalk juice concentration under the same corn stalk juice volume, and vice versa. Runoff reduction benefit was $32 \%, 35 \%, 39 \%, 56 \%, 63 \%$ and $76 \%$, respectively, for T1, T2, T3, T4, T5 and T6 treatments. Erosion reduction benefit was $38 \%, 42 \%, 65 \%, 77 \%, 89 \%$ and $96 \%$, respectively, for $\mathrm{T} 1, \mathrm{~T} 2, \mathrm{~T} 3, \mathrm{~T} 4, \mathrm{~T} 5$ and $\mathrm{T} 6$ treatments. The effect of corn stalk juice on erosion was more obvious than that on runoff when the corn stalk juice concentrations and volumes both were the same. The present study provides insight into the development of corn stalk juice as a useful soil amendment.

Keywords: soil amendment; corn stalk juice; runoff; erosion; aggregate stability; simulated rainfall 


\section{Introduction}

Soil erosion by water is one of the most widespread and major ecological and environmental problems worldwide which results in reduced agricultural productivity, increased water pollution, and affects sustainable development (Novara et al., 2011; Palacio et al., 2014; Adugna et al., 2015; Prosdocimi et al., 2016a). In many cases, water erosion causes a nearly irreversible decline in soil productivity and other soil functions, resulting in environmental damage. Accordingly, the prevention and control of soil erosion by water is of paramount importance for the management and conservation of natural resources (Tejada and Gonzalez, 2006; Cerdà et al., 2009; Liu et al., 2011; Keesstra et al., 2016a, 2016b) and has been paid much attention (Asselman et al., 2003; Weltzin et al., 2003; Singer and Shainberg, 2004; Nearing et al., 2005; Jin et al., 2008; Sun et al., 2014; Ngetich et al., 2014).

Towards this attempt, application of different wastes as soil amendments is therefore one of the effective methods in order to control soil erosion as well as to manage large amounts of wastes potentially produced worldwide to fulfill human needs (Smets et al., 2008; Sadeghi et al., 2015a, 2015b, 2016; Yazdanpanah et al., 2016). The application of organic wastes, such as sewage sludge (Tejada and Gonzalez, 2007; Singh and Agrawal, 2008; Pengcheng et al., 2008; Hueso-González et al., 2014; Hu et al., 2015), crop residues (Jiang et al., 2011; Li et al., 2011; Fernández et al., 2012; Liu et al., 2012; Gholami et al., 2012 ; Gholami et al., 2013; Shi et al., 2013; Fernández and Vega, 2014; Moreno-Ramón et al., 2014; Sadeghi et al., 2015a, 2015b, 2016; Peng et al., 2016), compost manure (Ramos and Martínez-Casasnovas, 2006; Tejada and Gonzalez, 2007; Lentz et al., 2014; Doan et al., 2015; Peng et al., 2016), 
byproducts with a high organic matter content (Tejada and Gonzalez, 2007; Larney and Angers, 2012; Jiménez et al., 2015; Hazbavi and Sadeghi, 2016; Prosdocimi et al., 2016b) and synthetic organic polymers, i.e., polyacrylamides (PAMs) (Flanagan and Canady, 2006; Teo et al., 2006; Mamedov et al., 2010; Lee et al., 2011; Tümsava and Kara, 2011; Liu et al., 2014; Inbar et al., 2015; Doan et al., 2015; Wang et al., 2015), to soils has become increasingly common in an attempt to maintain soil organic matter, reclaim degraded soils and supply plant materials. Previous studies have been conducted about application of soil amendments to improve soil structure (e.g., Karami et al., 2012; Brevik et al., 2015), change soil and water behavior (e.g., Huang et al., 2014) and reduce runoff and soil erosion in recent years (e.g., Prats et al., 2014; Rodrigo Comino et al., 2016). Although different soil amendments have been tested to protect soil, improve soil quality, and to reduce runoff and control soil erosion throughout the globe, there is still a need to seek natural products that may provide the same soil and water conservation benefits (Gholami et al., 2012).

In the process of developing green biomass utilization, such as fiber extraction, the plant juice becomes a natural byproduct because only water is used in the extraction. Harvesting green biomass may cause soil conservation challenges due to the reduced amount of organic materials left on the soil surface. One possible trade-off is to return the plant juice back to the soil as an amendment. The review of the scientific literature published about amendments in soil and water conservation shows us that the use of corn stalk juice, a kind of plant juice, as a soil amendment has not been investigated and reported yet.

In addition, the most widely used method to study the effects of soil amendments on soil 
erosion has been to apply simulated rainfall under laboratory conditions on disturbed soils because they are more rapid, efficient, controlled and adaptable than natural rainfall research (Moreno-Ramon et al., 2014; Lassu et al., 2015).

Consequently, in the present study, we hypothesized that the addition of corn stalk juice to the soil can be an effective method to reduce runoff and control soil erosion. A rainfall simulator was employed in the laboratory. The objective of this study, therefore, was to evaluate the effects of corn stalk juice on runoff and soil erosion reduction under simulated rainfall in the lab.

\section{Materials and methods}

\subsection{Test materials}

The surface soil materials were obtained from a Crosby-Miami complex Alfisol containing 20\% clay, $66 \%$ silt and 14\% sand from the Purdue Animal Science Research and Education Center (a typical region with hills and erosion), West Lafayette, Indiana, USA, located at a latitude of $40^{\circ} 29^{\prime} 24^{\prime \prime} \mathrm{N}$, longitude of $87^{\circ} 00^{\prime} 54^{\prime \prime} \mathrm{W}$. The soil was collected from the top layer of $0 \sim 10 \mathrm{~cm}$ of the profile. The test soil was air-dried, crushed and subsequently passed through an 8-mm sieve to obtain maximum similarity with the soil natural conditions (Defersha et al., 2011; Ziadat et al., 2013; Khaledi Darvishan et al., 2014; Sadeghi et al., 2015b) after pebbles and plant residues had been removed. The corn stalk juice used in the present study was extracted from field corn plants grown at the Purdue Agronomy Farm in West Lafayette, Indiana. The general properties of the extracted corn stalk juice are shown in Table 1. 


\subsection{Experiment layout and treatments}

The laboratory experiments were conducted at the USDA-ARS National Soil Erosion Research Lab in West Lafayette, Indiana. Four 0.5-m-long, 0.2-m-wide and 0.1-m-deep soil boxes with runoff collecting troughs at the outlet end were fabricated. The designed soil box slope was $5 \%$. At the bottom of the soil box, three rows of holes with $0.05-\mathrm{m}$ spacing per row and three drainage holes per row were drilled for water drainage from the box. Before filling the soil box, a small sponge was inserted into each bottom drainage hole. A 0.02-m layer of sand was laid at the bottom of the soil box in order to simulate natural drainage condition and decreasing plot weight (Defersha et al., 2011; Khaledi Darvishan et al., 2014). A 0.05-m thick test soil layer was then placed on the top and separated from the sand by a sheet of landscape fabric (Defersha et al., 2011; Khaledi Darvishan et al., 2014). The soil was ultimately compacted by a wood block to achieve the bulk density of $1.3 \mathrm{~g} \mathrm{~cm}^{-3}$ almost equal to that measured for the soil under natural conditions (Sadeghi et al., 2015b). Before packing, the gravimetric water content of the soil was adjusted to $12 \%$, the typical level during the flood season in this area when most erosion occurs. After the soil was packed, corn stalk juice by volume concentration of $25 \%, 50 \%$ and $75 \%$ were prepared in 0.4 and $0.8 \mathrm{~L}$, respectively, and uniformly applied on the surface of the plots from a perforated plastic bottle. After corn stalk juice application, the soil surface was dried thoroughly for one week prior to rainfall simulation.

The corn stalk juice treatments involved three application concentrations $(25 \%, 50 \%$ and $75 \%)$ and two application volumes ( 0.4 and $0.8 \mathrm{~L})$. One control (CK, $0.4 \mathrm{~L}$ deionized water) 
and six experimental treatments (T1, $0.1 \mathrm{~L}$ corn stalk juice mixed with $0.3 \mathrm{~L}$ deionized water, T2, $0.2 \mathrm{~L}$ corn stalk juice mixed with $0.2 \mathrm{~L}$ deionized water, $\mathrm{T} 3,0.3 \mathrm{~L}$ corn stalk juice mixed with $0.1 \mathrm{~L}$ deionized water, T4, $0.2 \mathrm{~L}$ corn stalk juice mixed with $0.6 \mathrm{~L}$ deionized water, $\mathrm{T}$, 0.4 L corn stalk juice mixed with $0.4 \mathrm{~L}$ deionized water, T6, $0.6 \mathrm{~L}$ corn stalk juice mixed with $0.2 \mathrm{~L}$ deionized water) were designed and three replicates per treatment, totalizing 21 experimental units.

\subsection{Rainfall simulation and measurements}

After one-week air drying, the treated soil box was for the rainfall simulation run. The soil box was placed under two programmable rainfall simulators equipped with oscillating VeeJet nozzles (Part no. 80100, Spraying Systems Co., Wheaton, IL). Two boxes were under the simulation at a time. The distance between the upslope end of the soil box and the rainfall nozzle was approximately $2.45 \mathrm{~m}$. The rainfall simulator was programmed to produce rainfalls at $25,50,75$ and $100 \mathrm{mmh}^{-1}$.

A 100-min duration rainstorm was employed. The storm comprised four intensity sequences: $50 \mathrm{mmh}^{-1}$ for $60 \mathrm{~min}, 25 \mathrm{mmh}^{-1}$ for $20 \mathrm{~min}, 75 \mathrm{mmh}^{-1}$ for $10 \mathrm{~min}$ and $100 \mathrm{mmh}^{-1}$ for 10 min (Huang and Laften, 1996). The runoff samples were collected in 1-liter HDPE bottles every $5 \mathrm{~min}$ for the two lower intensity rainfalls $\left(25\right.$ and $50 \mathrm{mmh}^{-1}$ ) and every $3 \mathrm{~min}$ for the two higher intensity rains $\left(75\right.$ and $\left.100 \mathrm{mmh}^{-1}\right)$. Time to fill the runoff bottle was recorded.

After each run, the sample bottles were immediately weighed to determine the runoff volume. Approximately $5 \mathrm{ml}$ of saturated alum solution was added to the sample bottles to 
flocculate the suspended sediment. After settling overnight, the upper clean (excess) water was drained from the bottles. The bottles were subsequently incubated in an oven at $105{ }^{\circ} \mathrm{C}$ for at least $24 \mathrm{~h}$ or until the sediments were dried. The dry weights were recorded to calculate the sediment delivery rate and concentration. The runoff reduction benefit (\%), erosion reduction benefit (\%), ratio between erosion and runoff reduction (\%) were calculated by formulas as following:

$$
\begin{aligned}
& R R B=\frac{R_{t}-R_{c}}{R_{c}} \times 100 \% \\
& E R B=\frac{E_{t}-E_{c}}{E_{c}} \times 100 \% \\
& R E R R=\frac{E_{t}-E_{c}}{R_{t}-R_{c}}
\end{aligned}
$$

where $R_{t}$ and $R_{c}$ are the runoff $(\mathrm{L})$ for controls and various treated plots, respectively, $E_{t}$ and $E_{c}$ are the erosion (g) for controls and various treated plots, respectively.

Aggregate sizes on the surface $(0-1 \mathrm{~cm})$ were measured by wet sieving after rainfall in the classes $>5,2-5,1-2,0.5-1,0.25-0.5$ and $<0.25 \mathrm{~mm}$. Each class of aggregates was dried and weighed. Three samples were measured for each treatment and averaged.

All data were analyzed using SPSS 22.0 by one-way ANOVA and Duncan tests. For all analyses of Tables 2-4, the significant level was 0.05 .

\section{Results}

\subsection{Effects on runoff}

The resulting runoff rates under various corn stalk juice treatments and control at different rainfall intensities on a designed slope gradient of $5 \%$ during the whole rainfall are 
completely given in Fig.1. In overall, the positive effects of corn stalk juice on runoff rate were manifested. Runoff rates under different treatments were all lower than that of the control. Corn stalk juice reduced runoff rates at various corn stalk juice treatments and rainfall intensities during the whole rainfall duration. As expected, corn stalk juice was able to reduce runoff rate. In general, the effect of corn stalk juice on runoff rate in T4, T5, T6 treatments was stronger than that in the $\mathrm{T} 1, \mathrm{~T} 2, \mathrm{~T} 3$ treatments.

Moreover, runoff rate, cumulative runoff, runoff reduction benefit at different rainfall intensities under various treatments are shown in Table 2. As shown in Table 2, all corn stalk juice treatments reduced the runoff rate, and cumulative runoff at various rainfall intensities. The T6 treatment had powerful conservation effects on runoff at all rainfall intensities compared to five other conservation treatments. Runoff rate and cumulative runoff both were the highest for the control experiment. Effects of corn stalk juice treatments on runoff ranked $\mathrm{T} 6>\mathrm{T} 5>\mathrm{T} 4>\mathrm{T} 3>\mathrm{T} 2\rangle \mathrm{T} 1$. In addition, the runoff rate increased with increasing rainfall intensity under the same corn stalk juice application concentration and volume. Cumulative runoff was 86.16, 58.86, 56.35, 52.15, 37.54, 31.73 and $20.37 \mathrm{~L}$, respectively, for control, T1, T2, T3, T4, T5 and T6. The significance test indicated that runoff rate of T1, T2, T3, T4, T5 and T6 treatments at different rainfall intensities showed significant difference $(\mathrm{P}<0.05)$. Runoff reduction benefit was $32 \%, 35 \%, 39 \%, 56 \%, 63 \%$ and $76 \%$, respectively, for $\mathrm{T} 1, \mathrm{~T} 2, \mathrm{~T} 3, \mathrm{~T} 4$, T5 and T6 treatments. Therefore, corn stalk juice could significantly reduce runoff in slope land at different rainfall intensities under a similar slope gradient. In general, the bigger the 
corn stalk juice concentration and volume were, the smaller the resulting runoff rate and cumulative runoff, and the larger the runoff reduction benefit was.

Further, runoff reduction benefits for various treatments at different rainfall intensities are shown in Fig.2. Generally, the reduction of runoff was relatively larger at middle rainfall intensities.

\subsection{Effects on erosion}

Runoff and erosion occurred and evolved simultaneously and were thus closely related.

Runoff caused erosion, so a reduction in runoff led to less erosion. The erosion rate with different corn stalk juice at different rainfall intensities are shown in Fig 3. In general, erosion rates under various corn stalk juice treatments were lower than that in the control at different rainfall intensities. Corn stalk juice reduced erosion rates at various corn stalk juice treatments and rainfall intensities during the whole rainfall duration. As expected, corn stalk juice was able to reduce erosion rate, too. In general, the effect of corn stalk juice on runoff rate on T4, T5, T6 treatments were stronger than that on $\mathrm{T} 1, \mathrm{~T} 2, \mathrm{~T} 3$ treatments.

The results of erosion rate, cumulative erosion, erosion reduction benefit at different rainfall intensities under various corn stalk juice treatments are shown in Table 3. As shown in Table 3, various corn stalk juice treatments mitigated erosion rate and cumulative erosion. The strongest conservation effects on erosion rate and cumulative erosion at different rainfall intensities were observed in the T6 treatment, while the conservation of five other treatments was still powerful. Erosion rate and cumulative erosion for the control experiment were the largest. Influences of corn stalk juice on erosion ranked T6 $>\mathrm{T} 5\rangle \mathrm{T} 4\rangle \mathrm{T} 3\rangle \mathrm{T} 2\rangle \mathrm{T} 1$. Moreover, the erosion rate increased with increasing rainfall intensity under the same corn stalk juice 
treatment. Cumulative erosion was 147.58, 91.62, 85.61, and 52.23, 33.62, 16.87 and $6.58 \mathrm{~g}$, respectively, for control, T1, T2, T3, T4, T5 and T6 treatments. The significance test indicated that erosion rate at different rainfall intensities showed significant difference $(\mathrm{P}<0.05)$. Erosion reduction benefit was $38 \%, 42 \%, 65 \%, 77 \%, 89 \%$ and $96 \%$, respectively, for T1, T2, T3, T4, T5 and T6 treatments. Therefore, corn stalk juice could significantly decrease erosion at different rainfall intensities under similar slope gradients in slope land. The higher the corn stalk juice application volume and concentration were, the lower the erosion rate and cumulative erosion were, thus the bigger the erosion reduction benefit.

In addition, erosion reduction benefits for various treatments at different rainfall intensities are shown in Fig.4. In overall, the reduction of erosion was relatively bigger at middle and high rainfall intensities.

\subsection{Contrast of effects on runoff and erosion}

Further analysis showed that the ratio between erosion and runoff reduction could be employed to analyze the characteristics of erosion and runoff for different treatments. According to Eq. (3), this ratio represents the relative effectiveness of erosion reduction to runoff reduction. For a given treatment, a larger ratio between erosion and runoff means that the role of the corn stalk juice is more effective in reducing erosion than in reducing runoff. The ratio between erosion and runoff reduction for various treatments at different rainfall intensities is illustrated in Fig. 5. Generally, the ratio between erosion and runoff reduction of two high rainfall intensities were higher than that of two low rainfall intensities in various corn stalk juice treatments. Erosion reduction benefits were also better than runoff reduction 
benefits under the same corn stalk juice treatment. The ratio of erosion and runoff reduction was biggest at rainfall intensities of $100 \mathrm{mmh}^{-1}$.

In addition, the result showed that runoff reduction benefit for $\mathrm{T} 2$ and $\mathrm{T} 4$ treatments was $35 \%$ and $56 \%$, respectively, erosion reduction benefit for $\mathrm{T} 2$ and $\mathrm{T} 4$ was $42 \%$ and $77 \%$, respectively (Table 2 and Table 3). Therefore, runoff reduction benefit and erosion reduction benefits in $\mathrm{T} 4$ treatment were better than those in $\mathrm{T} 2$ treatment. Likewise, the same phenomena occurred between T3 and T4 treatments. Although corn stalk juice employed in the $\mathrm{T} 3$ treatment $(0.3 \mathrm{~L})$ was more than that in the $\mathrm{T} 4$ treatment $(0.2 \mathrm{~L})$. The runoff reduction benefit (39\%) and erosion reduction benefit $(65 \%)$ for $\mathrm{T} 3$ treatment both were lower than those $(56 \%$ and $77 \%)$ for $\mathrm{T} 4$ treatment due to deionized water used in $\mathrm{T} 4$ treatment $(0.6 \mathrm{~L})$ and were five times more than that in T3 treatment $(0.1 \mathrm{~L})$, see Table 2 and Table 3 . Therefore, it is necessary to conduct research on the same corn stalk juice dilute on with different deionized water in the further study. This is of utmost importance for corn stalk juice as a kind of soil amendment to extend to field application.

\subsection{Effects on aggregate}

The effect of corn stalk juice on the soil surface aggregates after applying corn stalk juice was also shown in Table 4. These results were averages of all experiments at the same corn stalk juice treatment. Corn stalk juice effectively promoted the aggregation of small particles into larger particles. The percent mass of particles $<0.25 \mathrm{~mm}$ was drastically lowered, while the mass of each class $>0.25 \mathrm{~mm}$ increased. In the control, the percent mass of aggregates $>0.25 \mathrm{~mm}$ was only $23.4 \%$, but the percentage increased to $48.6 \%, 59.2 \%, 70.3 \%, 78.3 \%, 83.5 \%$ and $86.3 \%$, respectively, for $\mathrm{T} 1, \mathrm{~T} 2, \mathrm{~T} 3, \mathrm{~T} 4, \mathrm{~T} 5$ and $\mathrm{T} 6$ treatments. The improvement in the $0.25-0.5$ and 
$0.5-1 \mathrm{~mm}$ class to the six treatments was relatively small, while the improvement in the $1-2,2-5$ and $>5 \mathrm{~mm}$ classes was significant, especially at $\mathrm{T} 3, \mathrm{~T} 4, \mathrm{~T} 5$ and $\mathrm{T} 6$ treatments. The improvement of six corn stalk juice treatments of $\mathrm{T} 1, \mathrm{~T} 2, \mathrm{~T} 3, \mathrm{~T} 4, \mathrm{~T} 5$ and $\mathrm{T} 6$ on particles of every mass fraction of size class varied, but the treatments with higher volumes and concentrations had more particles $>0.25 \mathrm{~mm}$. The viscosity of corn stalk juice can increase the stability of soil aggregates and structure, thereby leading to stabilization of the soil surface against shear-inducing detachment, decreasing soil loss. A high stability of soil aggregates can also maintain an appropriate region of infiltration capacity for reducing surface runoff and eroded sediment.

\section{Discussions}

Our results demonstrate the potential benefit of using corn stalk juice to reduce runoff and soil erosion under various treatments at different rainfall intensities. The addition of corn stalk juice on the soil surface can effectively change the structure of the soil surface, maintain a high infiltration rate to limit runoff, reduce the detachment and transport of soil particles and ultimately reduce erosion. This finding agreed with the results of previous studies (Green et al., 2004; Adekalu et al., 2007; Groen and Woods, 2008; Smets et al., 2008; Mamedov et al., 2010; Jordan et al., 2010; Jiang et al., 2011; Li et al., 2011; Gholami et al., 2013; Fernandez and Vega, 2014; Sadeghi et al., 2015b) which showed that the organic amendments could lead to an increase in the stability of the aggregates compared with the untreated ones, and finally reduced runoff and erosion.

Our results also demonstrate that the higher the corn stalk juice concentration was, the larger the runoff reduction benefit and erosion reduction benefit under the same application 
volume. Similarly, the higher the application volume was, the bigger the runoff reduction benefit and erosion reduction benefit under the same corn stalk juice application concentration. And also, the high application volume of corn stalk juice could increase the runoff reduction and erosion reduction benefit more than those of the low application volume. The probable reason for these results was that the higher the corn stalk juice concentration and application volume were, the stronger the stability of the aggregates. These findings are in accordance with other authors (Gholami et al., 2013; Fernandez and Vega, 2014; Sadeghi et al., 2015b) who showed that the effect of organic amendment increased with increasing application of organic amendment.

In addition, the effect of corn stalk juice on the soil erosion reduction was stronger than the runoff reduction under the same corn stalk juice treatment. This is in agreement with the results of previous studies (Wu et al., 2010; Sadeghi et al., 2015b, 2016; Inbar et al., 2015) which showed that the effect of soil amendment on soil erosion was better than runoff. This behavior may be due to different soil conditions, steepness and length of the slope, scale of the plot, properties and degradation of corn stalk juice and rainfall duration.

Furthermore, although the present study was conducted in small plots, the results appear still reasonable because of the previous study performed the effects of plot size on runoff and soil loss control, confirming that different plot sizes revealed the same tendency (Sadeghi et al., 2015b). Therefore, although the research plot is not large, the result is still reliable. However, the previous study also showed that the small plot had a better effectiveness in reducing the runoff and erosion compared with the big plot (Sadeghi et al., 2015b). It remains 
important to carry out field tests under natural and disturbed environments for suggesting the optimum corn stalk juice dose.

Consequently, the corn stalk juice can be used as a kind of soil amendment to reduce runoff and control erosion. The natural byproduct of corn stalk juice as a soil amendment to combat soil erosion has potential based on the results of the present study. Our research opens a new way for the development of soil amendments, not only for corn, but also for other plants, especially for invasive plants in humid and semi-humid areas. If these kinds of plant juice can be used as soil amendments, turning the disadvantage into the advantage, and huge ecologic and economic benefits will be achieved.

\section{Conclusions}

Few studies have discussed the influences of corn stalk juice on the runoff and soil erosion control. This study evaluated the influences of corn stalk juice on runoff and erosion reduction benefit at small plot scale. Our experiments with simulated rainfall showed that corn stalk juice was able to reduce runoff and erosion. The effect of corn stalk juice on runoff and erosion at T4, T5, T6 treatments was stronger than those in T1, T2, T3 treatments. The effect of corn stalk juice on runoff and erosion was increased with the application volume and concentration. Moreover, the effect of corn stalk juice on erosion was stronger than runoff. Corn stalk juice also played a significant role in improving the composition of surface-soil aggregates, and the effects were larger as the concentration increased. The mass of each class of aggregates $>0.25 \mathrm{~mm}$ increased effectively. Furthermore, this study for the first time, to our knowledge, reports that stalk juice from corn is advantageous runoff and erosion control. 
The results of this study can therefore be used to avoid soil degradation under conditions similar to those adopted herein. However, further comprehensive studies are needed to test the persistence of the effect on runoff and erosion reduction in detail before the widespread adoption of corn stalk juice as a soil amendment. Likewise, other important aspects such as the optimum application volume of corn stalk juice, the optimum volume ratio of corn stalk juice and deionized water, effect of corn stalk juice on soil organic matter and other plant juice all need to be well considered.

\section{Acknowledgements}

This study was supported by Grants from the National Natural Science Foundation of China (Nos. 41001154, 51109103, 51679115) and the Fundamental Research Fund for the Central Universities of China (lzujbky-2015-149, lzujbky-2016-173). Thanks to the CSC for supporting this one-year visiting program and to Prof. Chi-hua Huang for hosting the authors to conduct this research at USDA-ARS-NSERL and Purdue University, USA. Thanks also go to Dr. Qiuju Wu and Dr. Longshan Zhao for their helps during the rainfall experiments at NSERL-USDA. 


\section{References}

Adekalu, K. O., Olorunfemi, I. A., Osunbitan, J. A., 2007. Grass mulching effect on infiltration, surface runoff and soil loss of three agricultural soils in Nigeria. Bioresource technology. 98(4), 912-917.

Adugna, A., Abegaz, A., Cerdà, A. 2015. Soil erosion assessment and control in Northeast Wollega, Ethiopia. Solid Earth Discussions, 7(4),3511-3540.

Asselman, N.E.M., Middelkoop, H., van Dijk, P.M., 2003. The impact of changes in climate and land use on soil erosion, transport and deposition of suspended sediment in the River Rhine. Hydrological Processes. 17(16), 3225-3244.

Brevik, E. C., Cerdà, A., Mataixsolera, J., Pereg, L., Quinton, J. N., Six, J., and Van Oost, K.2015. The interdisciplinary nature of soil. Soil, 1(1), 117-129.

Cerdà, A., Flanagan, D. C., Bissonnais, Y. L., \& Boardman, J. 2009. Soil erosion and agriculture. Soil \& Tillage Research, 106(1), 107-108.

Defersha, M. B., Quraishi, S., Melesse, A., 2011. The effect of slope steepness and antecedent moisture content on interrill erosion, runoff and sediment size distribution in the highlands of Ethiopia. Hydrology and Earth System Sciences. 15(7), 2367-2375.

Doan, T. T., Henry-des-Tureaux, T., Rumpel, C., Janeau, J. L., Jouquet, P., 2015. Impact of compost, vermicompost and biochar on soil fertility, maize yield and soil erosion in Northern Vietnam: A three year mesocosm experiment. Science of the Total Environment. 514, 147-154.

Fernández, C., Vega J. A., 2014. Efficacy of bark strands and straw mulching after wildfire in NW Spain: Effects on erosion control and vegetation recovery. Ecological Engineering. 63, 50-57.

Fernández, C., Vega, J. A., Jiménez, E., Vieira, D. C. S., Merino, A., Ferreiro, A., \& Fonturbel, T., 2012. Seeding and mulching+ seeding effects on post - fire runoff, soil erosion and species diversity in Galicia (NW Spain). Land Degradation and Development. 23(2), 150-156.

Flanagan, D. C., Canady, N. H., 2006. Use of polyacrylamide in simulated land application of lagoon effluent: Part I. Runoff and sediment loss. Transactions of the ASABE. 49(5), 1361-1369.

Gholami, L., Sadeghi, S. H., \& Homaee, M., 2013. Straw mulching effect on splash erosion, runoff, and sediment yield from eroded plots. Soil Science Society of America Journal. 77(1), 268-278.

Gholami L., Sadeghi, S. H. R., Homaee, M.,2012. Efficiency of rice straw mulch as a soil amendment to reduce splash erosion. In Proceedings of a Symposium Held at the Institute of Mountain Hazards and Environment. CAS-Chengdu, China. pp. 11-15.

Green, V.S., Stott, D.E., Graveel, J.G., Norton, L.D., 2004. Stability analysis of soil aggregates treated with anionic polyacrylamides of different molecular formulations. Soil Sci. 169, 573-581. 
Groen, A. H., Woods, S. W., 2008. Effectiveness of aerial seeding and straw mulch for reducing post-wildfire erosion, north-western Montana, USA. International Journal of Wildland Fire. 17(5), 559-571.

Hazbavi, Z., Sadeghi, S. H. R. 2016. Potential effects of vinasse as a soil amendment to control runoff and soil loss. SOIL, 2(1), 71-78.

Hu, Y. L., Niu, Z. X., Zeng, D. H., Wang, C. Y. 2015. Soil Amendment Improves Tree Growth and Soil Carbon and Nitrogen Pools in Mongolian Pine Plantations on Post-Mining Land in Northeast China. Land Degradation \& Development, 26(8), 807-812.

Huang, C. H., Laften, J. M. 1996. Seepage and soil erosion for a clay loam soil. Soil Science Society of America Journal, 60(2), 408-416.

Huang, J., Wang, J., Zhao, X., Li, H., Jing, Z., Gao, X., Chen, X., Wu, P., 2014. Simulation study of the impact of permanent groundcover on soil and water changes in Jujube orchards on sloping ground. Land Degradation and Development, 27(4), 946-954.

Huang, W., Bai, Z., Hoefel, D., Hu, Q., Lv, X., Zhuang, G., Zhang, H., 2012. Effects of cotton straw amendment on soil fertility and microbial communities. Frontiers of Environmental Science and Engineering, 6(3), 336-349.

Hueso-González, P., Martínez - Murillo, J. F., Ruiz - Sinoga, J. D. 2014. The impact of organic amendments on forest soil properties under Mediterranean climatic conditions. Land Degradation \& Development, 25(6), 604-612.

Inbar, A., Ben-Hur, M., Sternberg, M., Lado, M., 2015. Using polyacrylamide to mitigate post-fire soil erosion. Geoderma, 239, 107-114.

Jiang L., Dami I., Mathers H. M., Dick W. A., Doohan D., 2011. The effect of straw mulch on simulated simazine leaching and runoff. Weed Science. 59(4), 580-586.

Jiménez, J., Guardia-Puebla, Y., Cisneros-Ortiz, M. E., Morgan-Sagastume, J. M., Guerra, G., \& Noyola, A. 2015. Optimization of the specific methanogenic activity during the anaerobic co-digestion of pig manure and rice straw, using industrial clay residues as inorganic additive. Chemical Engineering Journal, 259,703-714.

Jin, K., Cornelis, W.M., Gabriels, D., Schiettecatte, W., De Neve, S., Lu, J., Buysse, T., Wu, H., Cai, D., Jin, J., Harmann, R., 2008. Soil management effects on runoff and soil loss from field rainfall simulation. Catena. 75(2), 191-199.

Jordán, A., Zavala, L. M., \& Gil, J., 2010. Effects of mulching on soil physical properties and runoff under semi-arid conditions in southern Spain.Catena. 81(1), 77-85.

Karami, A., Homaee, M., Afzalinia, S., Ruhipour, H., and Basirat, S., 2012. Organic resource management: Impacts on soil aggregate stability and other soil physico-chemical properties. Agriculture, Ecosystems and Environment. 148, 22-28.

Keesstra, S., Pereira, P., Novara, A., Brevik, E.C., Azorin-Molina, C., Parras-Alcántara, L., Jordán, A., Cerdà, A. 2016a. Effects of soil management techniques on soil erosion in apricot orchards. Science of the Total Environment, 551-552, 357-366.

Keesstra, S. D., Bouma, J., Wallinga, J., Tittonell, P., Smith, P., Cerdà, A., Montanarella, L., Quinton, J. N., Pachepsky, Y., van der Putten, W. H., Bardgett, R. D., Moolenaar, S., Mol, G., Jansen, B., and Fresco, L. O. 2016b. The significance of soils and soil science 
towards realization of the United Nations Sustainable Develop-ment Goals, SOIL, 2, 111-128.

Khaledi Darvishan, A. V., Sadeghi, S. H. R. Homaee, M., Arabkhedri, M., 2014. Measuring sheet erosion using synthetic color-contrast aggregates. Hydrological Processes. 28(15). 4463-4471.

Larney, F. J., Angers, D. A., 2012. The role of organic amendments in soil reclamation: A review. Canadian Journal of Soil Science. 92(1), 19-38.

Lassu, T., Seeger, M., Peters, P., Keesstra, S. D., 2015. The Wageningen Rainfall Simulator: Set-up and Calibration of an Indoor Nozzle-Type Rainfall Simulator for Soil Erosion Studies. Land Degradation and Development. 26(6), 604-612.

Lee, S. S., Gantzer, C. J., Thompson, A. L., Anderson, S. H., 2011. Polyacrylamide efficacy for reducing soil erosion and runoff as influenced by slope. Journal of Soil and Water Conservation. 66(3), 172-177.

Lentz, R. D., Lehrsch, G. A., 2014. Manure and fertilizer effects on carbon balance and organic and inorganic carbon losses for an irrigated corn field.Soil Science Society of America Journal. 78(3), 987-1002.

Li, X. H., Zhang, Z. Y., Yang, J., Zhang, G. H, Wang, B., 2011. Effects of Bahia grass cover and mulch on runoff and sediment yield of sloping red soil in southern China. Pedosphere. 21(2), 238-243.

Liu, J.E., Wang, Z.L., Yang, X.M., Jiao, N., Shen, N., Ji, P.F., 2014. The impact of natural polymer derivatives on sheet erosion on experimental loess hillslope. Soil and Tillage Research. 139, 23-27.

Liu, X.B., Zhang, S. L., Zhang, X.Y., Ding, G.W., Cruse, R.M., 2011. Soil erosion control practices in Northeast China: A mini-review. Soil and Tillage Research. 117: 44-48.

Liu, Y., Taoa, Y., Wana, K. Y., Zhanga, G. S., Liub, D. B., Xiongb, G. Y., Chena, F., 2012. Runoff and nutrient losses in citrus orchards on sloping land subjected to different surface mulching practices in the danjiangkou reservoir area of China. Agricultural Water Management. 110, 34-40.

Mamedov, A.I., Wagner, L.E., Huang, C., Norton, L.D., Levy, G.J., 2010. Polyacrylamide effects on aggregate and structure stability of soils with different clay mineralogy. Soil Science Society of America Journal. 74(5), 1720-1732.

Moreno-Ramón, H., Quizembe, S. J., Ibáñez-Asensio, S., 2014. Coffee husk mulch on soil erosion and runoff: experiences under rainfall simulation experiment. Solid Earth. 5(2), 851-862.

Nearing, M.A., Jetten, V., Baffaut, C., Cerdan, O., Couturier, A.,Hernandez, M., Le Bissonnais, Y., Nichols, M.H., Nunes, J.P., Renschler, C.S., Souchere, V., van Oost, K., 2005. Modeling response of soil erosion and runoff to changes in precipitation and cover. Catena. 61(2-3), 131-154.

Ngetich, K.F., Diels, J., Shisanya, C.A., Mugwe, J.N., Mucheru-muna, M., Mugendi, D.N., 2014. Effects of selected soil and water conservation techniques on runoff, sediment yield and maize productivity under sub-humid and semi-arid conditions in Kenya. Catena. 121, 288-296. 
Novara, A., Gristina, L., Saladino, S. S., Santoro, A., Cerdà, A., 2011. Soil erosion assessment on tillage and alternative soil managements in a Sicilian vineyard. Soil and Tillage Research. 117, 140-147.

Palacio, R. G., Bisigato, A. J., Bouza, P. J. 2014. Soil erosion in three grazed plant communities in northeastern Patagonia. Land Degradation \& Development, 25(6), 594-603.

Peng, X., Zhu, Q. H., Xie, Z. B., Darboux, F., Holden, N. M., 2016. The impact of manure, straw and biochar amendments on aggregation and erosion in a hillslope Ultisol. Catena. 138, 30-37.

Pengcheng, G., Xinbao, T., Yanan, T., Yingxu, C., 2008. Application of sewage sludge compost on highway embankments. Waste Management. 28(9), 1630-1636.

Prats, S. A., dos Santos Martins, M. A., Malvar, M. C., Ben-Hur, M., Keizer, J. J., 2014. Polyacrylamide application versus forest residue mulching for reducing post-fire runoff and soil erosion. Science of the Total Environment. 468, 464-474.

Prosdocimi, M., Cerdà, A., Tarolli, P. 2016a. Soil water erosion on Mediterranean vineyards: A review. Catena, 141, 1-21.

Prosdocimi, M., Jordán, A., Tarolli, P., Keesstra, S., Novara, A., Cerdà, A. 2016b. The immediate effectiveness of barley straw mulch in reducing soil erodibility and surface runoff generation in Mediterranean vineyards. Science of The Total Environment, 547, 323-330.

Ramos, M. C., Martínez-Casasnovas, J. A., 2006. Erosion rates and nutrient losses affected by composted cattle manure application in vineyard soils of NE Spain. Catena. 68(2), 177-185

Rodrigo Comino, J., Iserloh, T., Lassu, T., Cerdà, A., Keesstra, S.D., Prosdocimi, M., Brings, C., Marzen, M., Ramos, M.C., Senciales, J.M., Ruiz Sinoga, J.D., Seeger, M., Ries, J.B., 2016. Quantitative comparison of initial soil erosion processes and runoff generation in Spanish and German vineyards. Science of the Total Environment, 565, 1165-1174.

Sadeghi, S. H. R., Gholami, L., Sharifi, E., Khaledi Darvishan, A., Homaee, M., 2015a. Scale effect on runoff and soil loss control using rice straw mulch under laboratory conditions. Solid Earth. 6(1), 1-8.

Sadeghi, S. H. R., Gholami, L., Homaee, M., \& Darvishan, A. K. 2015b. Reducing sediment concentration and soil loss using organic and inorganic amendments at plot scale. Solid Earth, 6(2), 445-455.

Sadeghi S. H., Hazbavi Z., Harchegani M. K., 2016. Controllability of runoff and soil loss from small plots treated by vinasse-produced biochar. Science of the Total Environment. 541, 483-490.

Shi, Z. H., Yue, B. J., Wang, L., Fang, N. F., Wang, D., Wu, F. Z., 2013. Effects of mulch cover rate on interrill erosion processes and the size selectivity of eroded sediment on steep slopes. Soil Science Society of America Journal. 77, 257-267.

Singer, M.J., Shainberg, I., 2004. Mineral soil surface crusts and wind and water erosion. Earth Surface Processes and Landforms. 29(9), 1065-1075. 
Singh, R. P., Agrawal, M., 2008. Potential benefits and risks of land application of sewage sludge. Waste management. 28(2), 347-358.

Smets, T., Poesen, J., Bochet, E., 2008. Impact of plot length on the effectiveness of different soil-surface covers in reducing runoff and soil loss by water. Progress in Physical Geography. 32(6), 654-677.

Sun, W.Y., Shao, Q. Q., Liu, J. Q., Zhai, J., 2014. Assessing the effects of land use and topography on soil erosion on the Loess Plateau in China. Catena. 121: 151-163.

Tejada, M., Gonzalez, J.L., 2006. The relationships between erodibility and erosion in a soil treated with two organic amendments. Soil and Tillage Research. 91(1),186-198.

Tejada, M., Gonzalez, J.L., 2007. Influence of organic amendments on soil structure and soil loss under simulated rain. Soil and Tillage Research. 93(1), 197-205.

Tejada, M., Gonzalez, J.L., 2008. Influence of two organic amendments on the soil physical properties, soil losses, sediments and runoff water quality. Geoderma. 145(3-4), 325-334

Teo, J.A., Ray, C., El-Swaify, S.A., 2006. Screening of polymers on selected Hawaii soils for erosion reduction and particle setting. Hydrological processes. 20(1), 109-125.

Tümsava, Z. and Kara, A., 2011. The Effect of Polyacrylamide (PAM) applications on infiltration, runoff and soil losses under simulated rainfall conditions.African Journal of Biotechnology. 10(15), 2894-2903.

Wang, H. Q., Zhao, Q., Zeng, D. H., Hu, Y. L., Yu, Z. Y. 2015. Remediation of a Magnesium - Contaminated Soil by Chemical Amendments and Leaching. Land Degradation \& Development, 26(6), 613-619.

Weltzin, J.F., Loik, M.E., Schwinning, S., Williams, D.G., Fay, P.A., Haddad, B.M., Harte, J.,Huxman, T.E., Knapp, A.K., Lin, G., Pockman, W.T., Shaw, M.R., Small, E.E., Smith, M.D., Smith, S.D., Tissue, D.T., Zak, J.C., 2003. Assessing the response of terrestrial ecosystems to potential changes in precipitation. BioScience. 53(10), 941-952.

Wu, S.F., Wu, P.T., Song,W.X., Bu, C.F., 2010. Study on the outflow processes of slope regulated by works and its effects on overland flow and sediment reduction. J. Hydraul. Eng. 41 (7), 870-875 (in Chinese).

Yazdanpanah, N., Mahmoodabadi, M., Cerdà, A. 2016. The impact of organic amendments on soil hydrology, structure and microbial respiration in semiarid lands. Geoderma, 266, 58-65.

Ziadat, F. M. and Taimeh, A. Y., 2013. Effect of rainfall intensity, slope and land use and antecedent soil moisture on soil erosion in an arid environment. Land Degradation and Development. 24(6), 582-590. 


\section{Figure Captions}

Fig. 1 Runoff rate variation with rainfall duration under various treatments at different rainfall intensities

Fig. 2 Runoff reduction benefit for various experiment treatments at different rainfall intensities

Fig. 3 Erosion rate variation with rainfall duration under various treatments at different rainfall intensities

Fig. 4 Erosion reduction benefit for experiment treatments at different rainfall intensities

Fig. 5 Ratio of erosion and runoff reduction for experiment treatments at different rainfall intensities 


\section{Table Title}

Table 1 Physical and chemical properties of corn stalk juice in the experiment

Table 2 Average runoff rate, cumulative runoff and runoff reductions benefit under different treatments

Table 3 Average erosion rate, cumulative erosion and erosion reductions benefit under different treatments

Table 4 Effect of corn stalk juice on aggregates. Statistical comparisons for the corn stalk juice dose in the same size 
Fig. 1 Runoff rate variation with rainfall duration under various treatments at different rainfall intensities

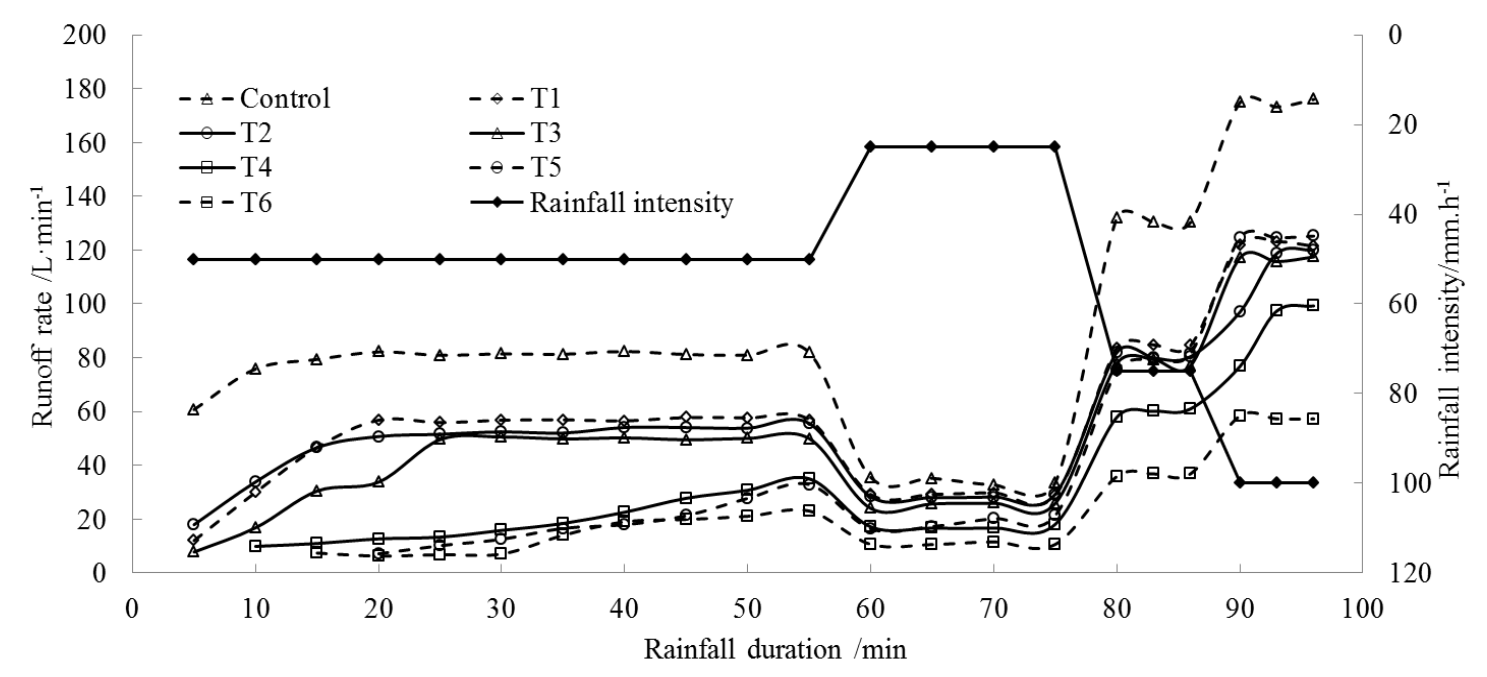

Fig. 2 Runoff reduction benefit for various experiment treatments at different rainfall intensities

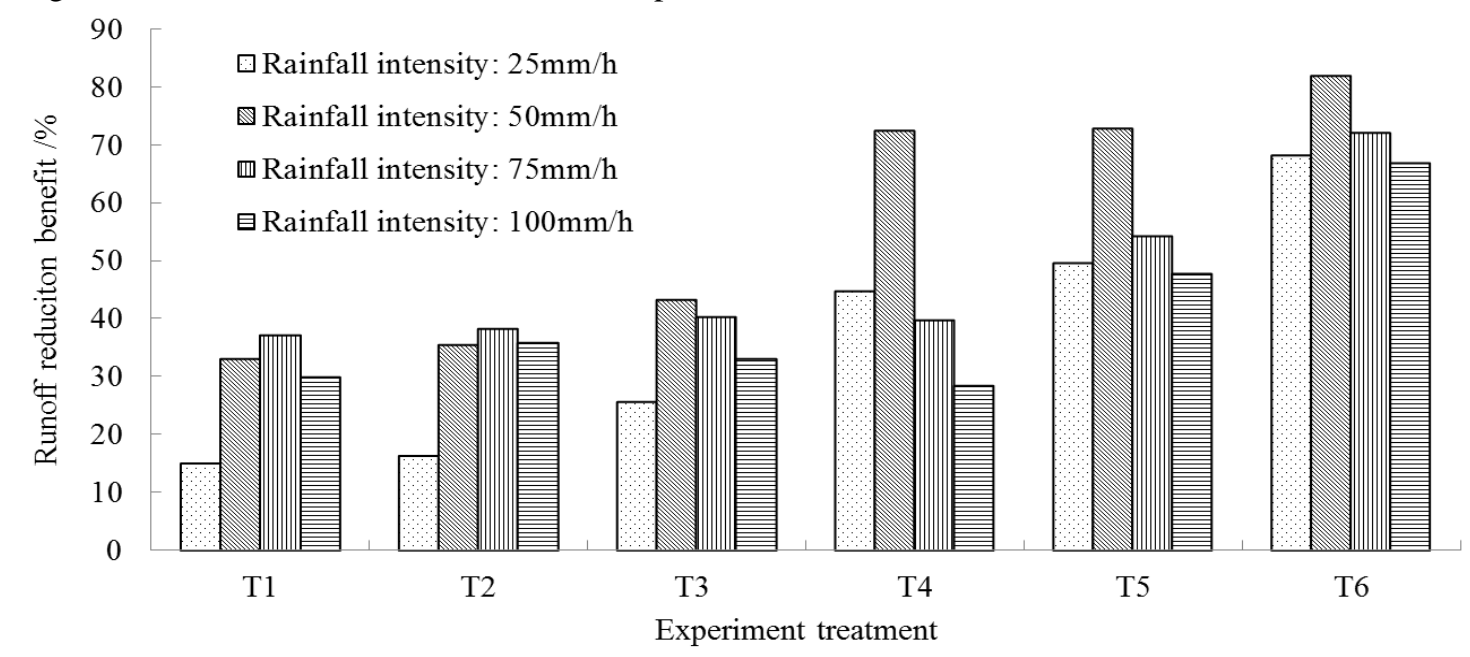


Fig. 3 Erosion rate variation with rainfall duration under various treatments at different rainfall intensities

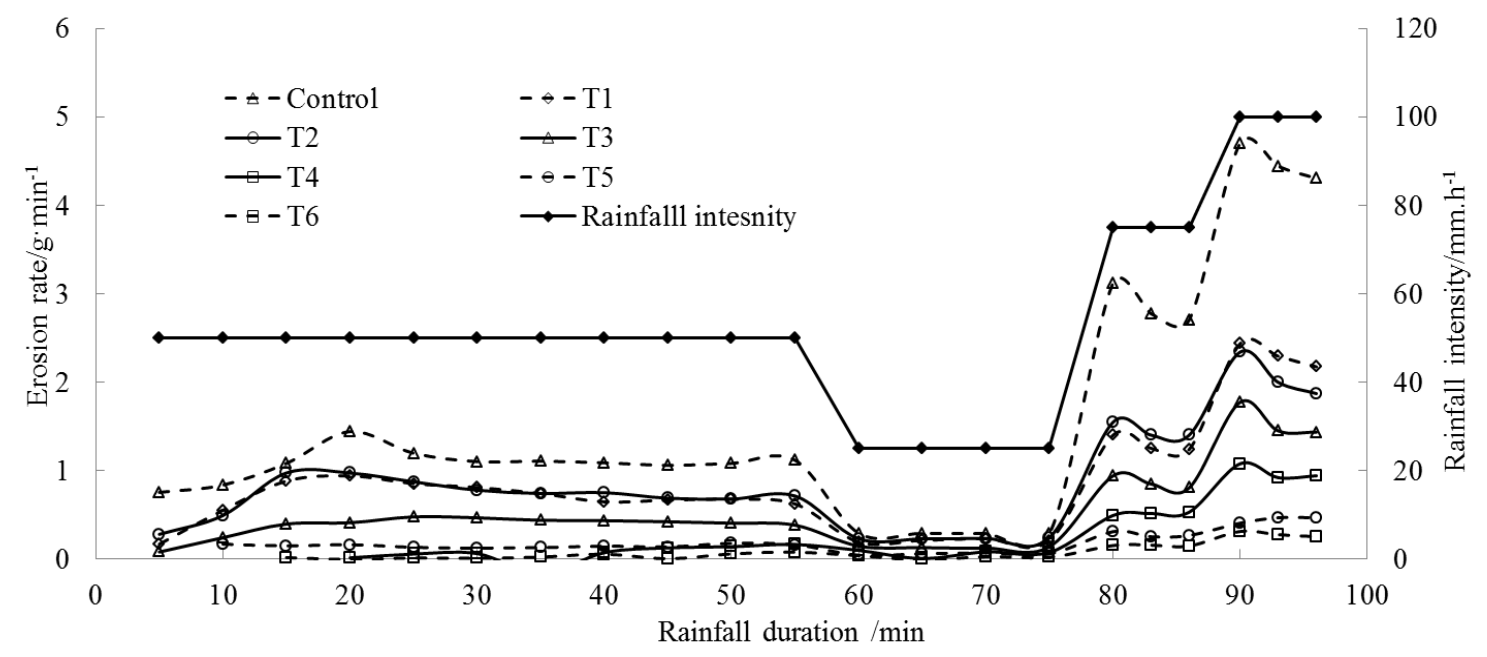

Fig. 4 Erosion reduction benefit for experiment treatments at different rainfall intensities

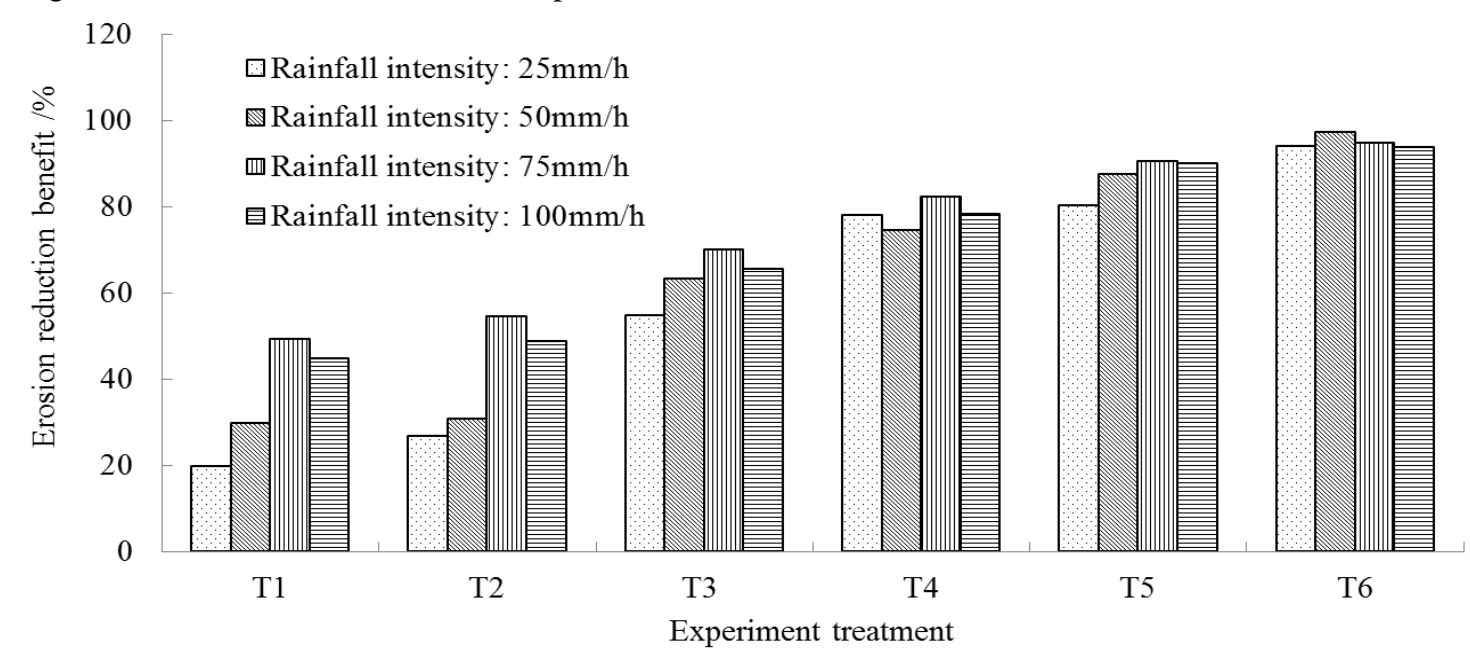


Fig. 5 Ratio of erosion and runoff reduction for experiment treatments at different rainfall intensities

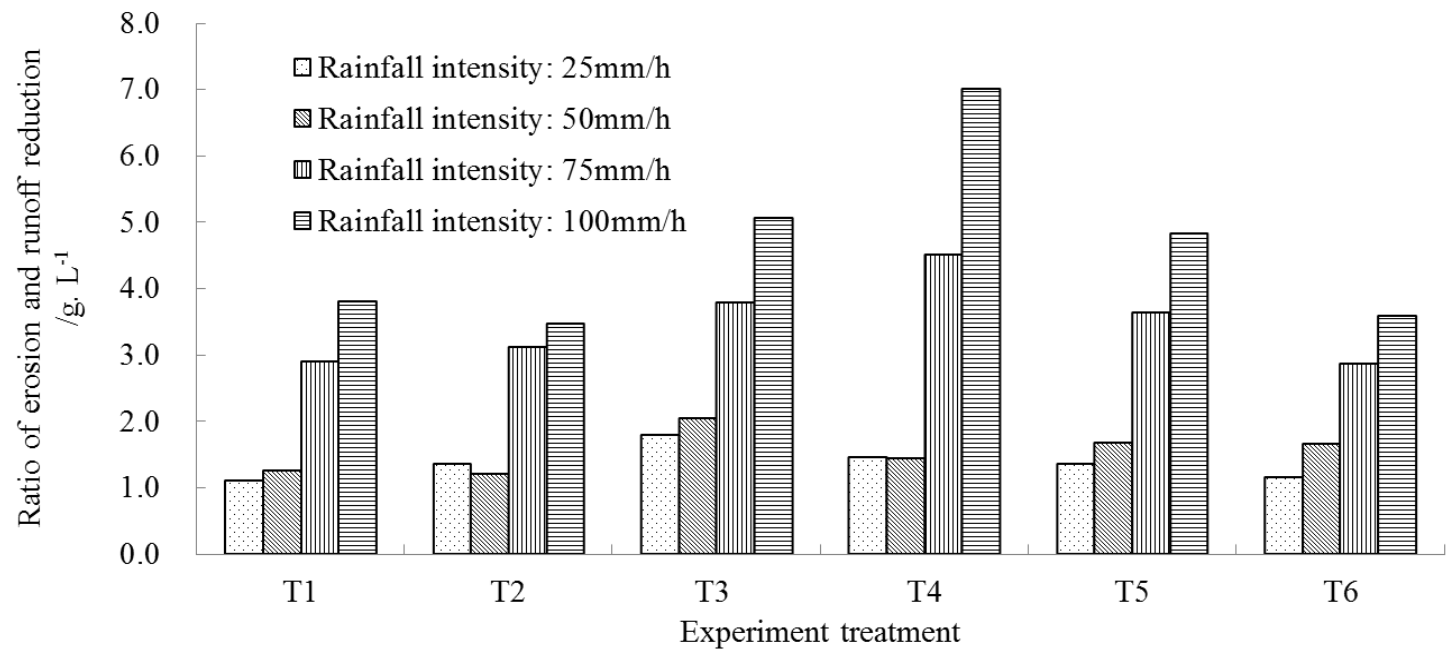


Table 1 Physical and chemical properties of corn stalk juice in the experiment

\begin{tabular}{cccc}
\hline Parameter & Unit & As received basis & Dry basis \\
\hline Moisture & $\%$ & 88.26 & \\
Dry Matter & $\%$ & 11.74 & \\
Nitrogen & $\%$ & 0.29 & 2.44 \\
Crude Protein & $\%$ & 1.83 & 15.25 \\
Calcium(Ca) & $\%$ & 0.09 & 0.78 \\
Potassium(K) & $\%$ & 0.56 & 4.78 \\
Magnesium(Mg) & $\%$ & 0.05 & 0.46 \\
Sodium(Na) & $\%$ & 0.01 & 0.06 \\
Phosphorus(P) & $\%$ & 0.04 & 0.35 \\
Sulfur(S) & $\%$ & 0.02 & 0.19 \\
Aluminum(Al) & ppm & 3 & 13 \\
Boron(B) & ppm & 1 & 10 \\
Copper(Cu) & ppm & 3 & 14 \\
Iron(Fe) & ppm & 3 & 26 \\
Manganese(Mn) & ppm & 2 & 9 \\
Zinc(Zn) & ppm & 3 & 23 \\
\hline
\end{tabular}

Table 2 Average runoff rate, cumulative runoff and runoff reduction benefits under different treatments

\begin{tabular}{|c|c|c|c|c|c|c|}
\hline \multirow{2}{*}{ Treatment } & \multicolumn{4}{|c|}{ Runoff rate at different rainfall intensities $\left(\mathrm{Lmin}^{-1}\right)$} & \multirow{2}{*}{$\begin{array}{l}\text { Cumulative } \\
\text { runoff (L) }\end{array}$} & \multirow{2}{*}{$\begin{array}{c}\text { Runoff reduction } \\
\text { benefit }(\%)\end{array}$} \\
\hline & 25 & 50 & 75 & 100 & & \\
\hline CK & $0.34 \mathrm{a}$ & $0.81 \mathrm{a}$ & $1.31 \mathrm{a}$ & $1.75 \mathrm{a}$ & $86.16 \mathrm{a}$ & \\
\hline $\mathrm{T} 1$ & $0.29 b$ & $0.54 b$ & $0.82 b$ & $1.22 \mathrm{c}$ & $58.86 b$ & $32 f$ \\
\hline $\mathrm{T} 2$ & $0.28 \mathrm{c}$ & $0.52 \mathrm{c}$ & $0.81 b$ & $1.12 \mathrm{e}$ & $56.35 \mathrm{c}$ & $35 \mathrm{e}$ \\
\hline $\mathrm{T} 3$ & $0.25 \mathrm{~d}$ & $0.46 \mathrm{~d}$ & $0.78 \mathrm{c}$ & $1.17 \mathrm{~d}$ & $52.15 \mathrm{~d}$ & $39 d$ \\
\hline $\mathrm{T} 4$ & $0.19 \mathrm{e}$ & $0.22 \mathrm{e}$ & $0.79 \mathrm{c}$ & $1.25 b$ & $37.54 \mathrm{e}$ & $56 \mathrm{c}$ \\
\hline T5 & $0.17 \mathrm{f}$ & $0.22 \mathrm{e}$ & $0.6 \mathrm{~d}$ & $0.91 \mathrm{f}$ & $31.73 \mathrm{f}$ & $63 b$ \\
\hline T6 & $0.11 \mathrm{~g}$ & $0.15 f$ & $0.37 \mathrm{e}$ & $0.58 \mathrm{~g}$ & $20.37 \mathrm{~g}$ & $76 a$ \\
\hline
\end{tabular}


Table 3 Average erosion rate, cumulative erosion and erosion reduction benefits under different treatments

\begin{tabular}{ccccccc}
\hline \multirow{2}{*}{ Treatment } & \multicolumn{2}{c}{ Erosion rate at different rainfall intensities $\left(\mathrm{gmin}^{-1}\right)$} & $\begin{array}{c}\text { Cumulative } \\
\text { erosion }(\mathrm{g})\end{array}$ & $\begin{array}{c}\text { Erosion reduction } \\
\text { benefit }(\%)\end{array}$ \\
\cline { 2 - 5 } CK & 25 & 50 & 75 & 100 & $147.58 \mathrm{a}$ & \\
$\mathrm{T} 1$ & $0.29 \mathrm{a}$ & $1.14 \mathrm{a}$ & $2.86 \mathrm{a}$ & $4.48 \mathrm{a}$ & & \\
$\mathrm{T} 2$ & $0.23 \mathrm{~b}$ & $0.8 \mathrm{~b}$ & $1.45 \mathrm{~b}$ & $2.48 \mathrm{~b}$ & $91.62 \mathrm{~b}$ & $48 \mathrm{f}$ \\
$\mathrm{T} 3$ & $0.21 \mathrm{c}$ & $0.79 \mathrm{c}$ & $1.3 \mathrm{c}$ & $2.3 \mathrm{c}$ & $85.61 \mathrm{c}$ & $65 \mathrm{~d}$ \\
$\mathrm{~T} 4$ & $0.13 \mathrm{~d}$ & $0.42 \mathrm{~d}$ & $0.86 \mathrm{~d}$ & $1.55 \mathrm{~d}$ & $52.23 \mathrm{~d}$ & $77 \mathrm{c}$ \\
T5 & $0.07 \mathrm{e}$ & $0.29 \mathrm{e}$ & $0.51 \mathrm{e}$ & $0.98 \mathrm{e}$ & $33.62 \mathrm{e}$ & $89 \mathrm{~b}$ \\
T6 & $0.02 \mathrm{~g}$ & $0.03 \mathrm{~g}$ & $0.15 \mathrm{~g}$ & $0.28 \mathrm{~g}$ & $6.58 \mathrm{~g}$ & $96 \mathrm{a}$ \\
\hline
\end{tabular}

Table 4 Effect of corn stalk juice on aggregates. Statistical comparisons for the corn stalk juice dose in the same size.

\begin{tabular}{|c|c|c|c|c|c|c|c|c|c|c|c|c|c|}
\hline \multirow{2}{*}{$\begin{array}{c}\text { Size } \\
\text { distribution } \\
(\mathrm{mm}) \\
\end{array}$} & \multicolumn{7}{|c|}{ Mass fraction of size classes $(\%)$} & \multicolumn{6}{|c|}{ Increasement compared to control (\%) } \\
\hline & control & $\mathrm{T} 1$ & $\mathrm{~T} 2$ & $\mathrm{~T} 3$ & $\mathrm{~T} 4$ & T5 & T6 & $\mathrm{T} 1$ & $\mathrm{~T} 2$ & $\mathrm{~T} 3$ & $\mathrm{~T} 4$ & T5 & T6 \\
\hline$<0.25 \mathrm{~mm}$ & $76.6 \mathrm{a}$ & $51.4 \mathrm{~b}$ & $40.8 \mathrm{c}$ & $29.7 \mathrm{~d}$ & $21.7 \mathrm{e}$ & $16.5 f$ & $13.7 \mathrm{~g}$ & -33 & -47 & -61 & -72 & -78 & -82 \\
\hline $0.25-0.5 \mathrm{~mm}$ & $13.9 f$ & $16.5 \mathrm{e}$ & $23.9 \mathrm{a}$ & $22.7 \mathrm{~d}$ & $23 c$ & $23 c$ & $23.4 b$ & 19 & 73 & 64 & 66 & 66 & 69 \\
\hline $0.5-1 \mathrm{~mm}$ & $5.8 \mathrm{f}$ & $15.9 \mathrm{a}$ & $14.1 \mathrm{~b}$ & $12.7 \mathrm{~d}$ & $13.9 \mathrm{c}$ & $14.1 b$ & $12.2 \mathrm{e}$ & 174 & 143 & 119 & 140 & 143 & 110 \\
\hline $1-2 \mathrm{~mm}$ & $2.9 \mathrm{~g}$ & $11.3 \mathrm{f}$ & $13.1 \mathrm{e}$ & $14.9 \mathrm{~d}$ & $17.8 \mathrm{c}$ & $18.6 b$ & $19.5 \mathrm{a}$ & 286 & 347 & 409 & 508 & 535 & 566 \\
\hline $2-5 \mathrm{~mm}$ & $0.9 \mathrm{~g}$ & $4.9 \mathrm{f}$ & $7.2 \mathrm{e}$ & $16.2 \mathrm{~d}$ & $19.3 \mathrm{c}$ & $22.7 b$ & $24.3 \mathrm{a}$ & 444 & 700 & 1700 & 2044 & 2422 & 2600 \\
\hline$>5 \mathrm{~mm}$ & 0 & 0 & $0.9 \mathrm{e}$ & $3.8 \mathrm{~d}$ & $4.3 \mathrm{c}$ & $5.1 b$ & $6.9 \mathrm{a}$ & & & & & & \\
\hline$>0.25 \mathrm{~mm}$ & $23.4 \mathrm{~g}$ & $48.6 \mathrm{f}$ & $59.2 \mathrm{e}$ & $70.3 \mathrm{~d}$ & $78.3 c$ & $83.5 b$ & $86.3 \mathrm{a}$ & 108 & 153 & 200 & 234 & 257 & 269 \\
\hline
\end{tabular}

